$90 \%$ on a weight basis and $94 \%$ by ultraviolet-light absorption The recoveries of the amıno acıds were quantitative by radioactivity measurement and by ultravioletlight absorption for tryptophan The separations were equivalent for each of the amino acids

When the proteolipid and amino acids were mixed in aqueous media as described above, the binding of amino acids was also demonstrated by use of the starch column, as illustiated in Fig 2 The proteolipids in the incubation mediums were recovered in $\mathrm{CHCl}_{3}-\mathrm{CH}_{3} \mathrm{OH}$, washed $7-9$ times, applied to the column, and eluted with the same solvent

The presence or absence of the compounds, tested above for their effect on the distribution coefficients, had no eftect on the congruence of the radioactivity and proteolipid elution peaks It was further seen that the addition of the following aqueous media to the eluant ( $I$ vol to Io vol of eluant) gave identical elution patterns water, I o $M$ formic acid, o I $M$ ammonium formate ( $\mathrm{pH} 37$ ), o or $M$ Tris-chloride ( $\mathrm{pH} 757$ ), o or $M \mathrm{CaCl}_{2}$ In each case the fraction with the maximum specific radioactivity also had the maximum dry weight, ultraviolet absorbancy and radioactivity

The two techniques used here demonstrate the existence of strong bonds between the amino acids and the proteolipid, which are not dissociated by the treatments used The intervention of enzymes in the binding seem, to be excluded

The author wishes to express his gratitude for stimulating and informative discussions with Drs J FOLCH-PI and M LEES

Research Laboratory, McLean Hospital, Belmont, Mass ( $S S A)$ L C MokR ASCH ${ }^{\star}$ P MANNER

1 J J W REN, Nature, I85 (I960) 295

2 O P Samarina, I B Zbarskit and K A Perevoshchikova, Biokhimiva, 25 (I960) 443

${ }^{3} \mathrm{~F}$ Karush, $J$ Am Chem Soc, 73 (195 I) 1246

${ }^{4} \mathrm{~J}$ Folch-PI, Exposes ann biochim med, $2 \mathrm{I}$ (I958) 8I

5 B LindQVist and T STORgårds, Nature, 75 (I955) 5 I I

${ }^{6}$ J Folch-PI, G R IVebster ANd M LEes, Federation Proc, I8 (1959) 228

Recelved February 26th, I962

* Special fellow of the National Institute of Neurological Diseases and Blindness, U S Public Health Service

Brochim Brophvs Acta, 60 (I962) 4I5-4I7

\title{
On the transformation of the fungicide sodium dimethyldithiocarbamate into its alanine derivative by plant tissues
}

DEKHUIJZEN ${ }^{1,2}$ reported that the fungicide sodium dimethyldithıcarbamate is transformed by plants into three other fungitoxic agents which can be distinguished by

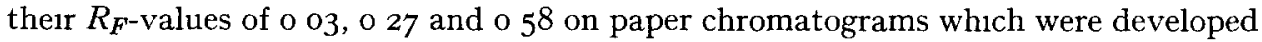
with propanol-water $(85 \mathrm{I} 5, \mathrm{~V} / \mathrm{v})$ and subsequently sprayed with the mould Glomerella cingulata in a nutrient solution A second, chemical, test for the demonstration of these compounds on the strip is the lodine-sodium azide reagent of FEIGL ${ }^{3}$ which indicates the presence of $\mathrm{C}=\mathrm{S}$ groups 
In a previous publication ${ }^{4}$ we reported the isolation of one of the compounds which is formed enzymically when potato slices are incubated in a solution of sodium dimethyldithiocarbamate This compound with the $R_{F}$ value of o 58 proved to be the $\beta$-glucoside of dimethyldithiocarbamate

We have now succeeded in isolating and identifying the compound with $R_{F}=027$ It was obtained together with the glucoside by incubation of $50 \mathrm{~kg}$ of potato slices in 501 of water containıng roo $\mathrm{g}$ of sodıum dimethyldithiocarbamate as previously described ${ }^{4}$ The compound appeared to be mainly present in the $x$ ap pressed from the slices This sap was treated with lead acetate at $\mathrm{pH} 70$ The precipitate was discarded and the excess of lead acetate removed with sodium phosphate The resulting filtrate was then concentrated $2 n$ vacuo and submitted to a countercurrent distribution between butanol - ethanol-water (52 II $37, v / v / v)$ By this procedure the compound with $R_{F}=027$ was purified and it was also separated from the glucoside The fractions which contained the compound with $R_{F}=027$ were pooled and concentrated A further purification could be achieved by partition chromatography on a cellulose column with propanol - water $(85 I 5, v / v)$ as a solvent The eluates containing the compound with $R_{F}=027$ were taken to dryness and the residue dissolved in the minimum amount of bolling propanol - water $(85 \mathrm{I} 5, \mathrm{~V} / \mathrm{V}$ ) After standing for some hours compound I crystallized as glistening flakes It was recrystallized from the same solvent and dried $\imath n$ vacuo at $80^{\circ}$ over $\mathrm{P}_{2} \mathrm{O}_{5}$ for $\mathrm{I} h$ Incubation of $50 \mathrm{~kg}$ potato slices with roo $\mathrm{g}$ sodium dimethyldithiocarbamate dissolved in $50 \mathrm{l}$ of water yielded $350 \mathrm{mg}$ of the pure compound I, as well as Io $\mathrm{g}$ of the glucoside Calc for $\mathrm{C}_{6} \mathrm{H}_{12} \mathrm{~N}_{2} \mathrm{O}_{2} \mathrm{~S}_{2} \mathrm{C}, 3459, \mathrm{H}, 582, \mathrm{~N}, \mathrm{I} 345, \mathrm{~S}, 3079$ Found $\mathrm{C}, 3476, \mathrm{H}, 567, \mathrm{~N}, \mathrm{I} 333, \mathrm{~S}, 30 \mathrm{o}$

Compound I appeared to be a neutral, optically active compound giving a poustir ninhydrin reaction Its empirical formula suggested that an amino acid with 3 carbon atoms might be attached to the dimethyldithiocarbamate structure In view of the fact that we had meanwhile demonstrated ${ }^{5}$ that sodium dimethyldithiocarbamate is converted by microorganisms into $\gamma$-(dimethylthiocarbamoylthio)- $\alpha$-aminobutyric acid $\left(\mathrm{CH}_{3}\right)_{2} \mathrm{~N} \mathrm{CS} \mathrm{S}\left(\mathrm{CH}_{2}\right)_{2} \mathrm{CHNH}_{2} \mathrm{COOH}$, we assumed that compound I might be the corresponding alanıne derivatıve, 'ız $\beta$-(dımethylthiocarbamoylthı)- $\alpha$-amınopropionic acid To gain definite proof the DL-form of this compound was synthesized by Dr Pllijgers and Mr Berg at this Institute This synthesin will be reported elsewhere Infrared spectra, $R_{F}$ values as well as behaviour to hydrolysis proved $t$, be identical We therefore conclude that compound I is $\beta$-(dimethylthiocarbamoylthio)-alanine, presumably the L-form

$$
\left(\mathrm{CH}_{3}\right)_{2} \mathrm{~N} \mathrm{CS} \rightarrow \mathrm{CH}_{2} \mathrm{CHNH}_{2} \mathrm{COOH}
$$

From the mother liquors of compound I another compound (II) also giving a positive reaction with lodine--sodium azide could be isolated This compound is not fungitoxic and could therefore not be detected with the Glomerella technique

The peculiar behaviour of compound $I$ to acid hydrolysis led us to the ident1fication of compound II Although, according to expectation, serine and cystine were formed by acid hydrolysis of $I$, the greater part is converted into another compound which could be isolated and crystallized To our surprise this substance appeared to be identical with II as followed from melting point, $R_{F}$ value and analysis Further 
investigation revealed the compound to be optically active thrazolidine-2-thione-4carboxylic acid

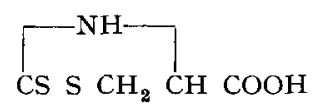

IVe have reason to suppose that the presence of II in the mother liquors is due to non-enzymic decomposition of I

TABLE I

GROWTH-INHIBITING ACTIVITY OF SODIUM DIMETHYLDITHIOCARBAMATE AND ITS ALANINE DERIVATIVE

\begin{tabular}{|c|c|c|}
\hline & \multicolumn{2}{|c|}{ Minmal conc giving complete growth inhuntion } \\
\hline & $\begin{array}{c}\text { Sodnum } \\
\text { dimethyld thocarbamate } \\
(p p m)\end{array}$ & $\begin{array}{c}\text { Compound I } \\
(p p m)\end{array}$ \\
\hline Glomerella cingulata ${ }^{\star}$ & I & 2 \\
\hline Aspergillus niger ** & $\mathbf{I}$ & 20 \\
\hline Cladosporıum cucumerinum ${ }^{\star \star}$ & 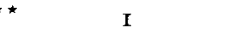 & 20 \\
\hline Botrytus allu & $\circ 5$ & 2 \\
\hline Hansenula anomala * & I & Io \\
\hline Saccharomyces cerevisiae ${ }^{\star \star \star}$ & 20 & $>50$ \\
\hline Bacullus subtults* & 2 & IO \\
\hline Bacteruum coln ${ }^{*}$ & $>$ IOO & $>100$ \\
\hline
\end{tabular}

Comparable values for the activity of sodium dimethyldithiocarbamate and its synthetıc DL-alanıne derivative against various micro-organısms are given in Table I We assume that toxicity of the latter compound is due to enzymic cleavage leading to the liberation of dimethyldithiocarbamate ion The activity of the L-alanine derivative was found to be equal to that of the DL- derivative This does not exclude the possibility that the $\mathbf{L}$ - form is split more readily that the $\mathrm{D}$ - form, as the accuracy of the test used is insufficient to solve this problem

Plant tissues thus appear to be able to convert dimethyldithocarbamate both into its $\beta$-glucoside and-to a much smaller extent-into its alanine derivative Aminotriazole is the only other foreign compound known to be converted into an alanine derivative by plant tissues ${ }^{6}$ It is remarkable that also in this case the glucoside is found as well 7
Instutute for Organuc Chemistry, $T N O$, Utrecht (The Netherlands)
A KaARS Sijpesteijn
G J M VAN DER KERK

J KASLANDER

${ }^{1}$ H M Dekhuijzen, Nature, I9I (I96I) I98

2 H M DEKHUIJZEN, Mededelingen Landbowwhogeschool Gent, 26 (I961) $\Upsilon_{542}$

${ }^{3} \mathrm{~F}$ Feigl, Spot Tests in Organic Analysis, Elsevier Publ Co, Amsterdam, I96o, p 242

4 J Kaslander, A Kaars Sijpesteijn and G J M van der Kerk, Biochim Biophys Acta, 52 (I96I) 396

5 A Kaars Sijpesteijn, J Kaslander and G J M van der Kerk, Brochim Biophys Acta, in the press

- P Massini, Blochim Biophvs Acta, 36 (I959) 548

7 J F Fredrick and A C Gentile, Physiol Plantarum, 13 (I960) $76 \mathrm{I}$

Recelved February I5th, 1962 